$66: 668$

<症例報告 $>$

B 型肝炎ウイルスキャリアからの急性発症を契機に見出された GPT Silent Allele の 1 例

\begin{tabular}{|c|c|c|c|c|c|c|c|}
\hline 川島 & 博 & 藤山 & 佳秀 & 安藤 & 朗 & 程原 & 佳子 \\
\hline 中條 & 忍 & 馬場 & 忠雄 & 細田 & 四郎* & 大梘 & 隆明 ** \\
\hline
\end{tabular}

\begin{abstract}
要 旨：GPT の可溶性画分である sGPT は，Gpt $G G p t^{2}$ の常染色体上の二つの対立遺伝子に

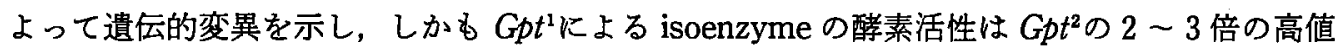
であることが知られている．また，Gpt $t^{1}, G p t^{2}$ 以外にも silent allele $\left(G p t^{0}\right)$ を含む種々の変異 遺伝子の存在む報告されている. 症例は47歳女性. 入院時 GOT, LDH, ALP 等は上昇を認め, $\mathrm{HBV}$ キャリアからの急性発症のパターンを呈したが, GPT のみは著明な低值を示し，GOT/ GPT 比に解離が認められた。赤血球 GPT 活性は， $0.82 \mathrm{U} / \mathrm{g} \mathrm{Hb}$ と低值で，電気泳動に打いて は，弱い帯であったが GPT 2 型と判定された。患者の母親の GPT 表現型は 1 型で, その活性 值は2.93U/g Hbであった。患者赤血球 GPT 活性が著しい低値を示したこと，GPT 表現型に おいて母親と遺伝的解離を認めたことは $G p t^{0}$ の存在を示唆した。本症例は $G p t^{0}$ heterozygote であったために急性発症の極期においてもGPT は上昇しなかったものと考えられた.
\end{abstract}

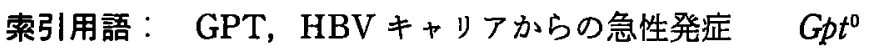

はじめに

Glutamic-pyruvic transaminase (以下 GPT) は, L-alanine $と \alpha$-ketoglutarate glutamate に相互変換する酵素であり，ミトコンドリ 了画分 (mGPT) と可溶性画分 (sGPT) の二つの molecular form に分けられる. 一方，上卜赤血球中の sGPT が遺层的变異を示すことが知られており，GPT 1, GPT 2-1, GPT 2 の common phenotype $と$, さら に silent allele (以下 $G p t^{0}$ ) を含めた種々の稀な variant の存在が報告されている1 11)。今回，我々はGPT 活性の著明に低下した $G p t^{0}$ の heterozygote と考光ら

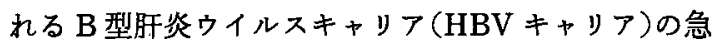
性発症の症例を経験したので報告する。

症例

患者：47歳，女性.

主訴：亜心，呕吐，食欲不振，全身供点感。

既往歷：43歳時に貧血，心室性期外収縮を指摘され

*嵫賀医科大学第 2 内科 $* *$ 同 検查部

**西京都病院内科

湖北総合病院内科

＜受付日1988年10月 6 日 $>$
た.

家族歴：特記すべきことなし.

現病歴：昭和 61 年 2 月頃より, 悪心, 呕吐, 食欲不 振，全身倦总感が出現したため，自宅にて安静にして いた，同年 3 月 7 日の健康診断にて，肝機能異常を指 摘されて入院となった。

入院時現症：身長 $153 \mathrm{~cm}$ ，体重 $49 \mathrm{~kg}$ ，血圧 $138 / 98$, 体温 $36.5^{\circ} \mathrm{C}$ ，皮痛，眼䀫結膜に黄疸と軽度の負血を認 めた．表在リンパ節は触知せず，胸部にも異常所見は 認めなかった，腹部では右鎖骨中線上に，辺縁鈍，弾 性硬, 表面平滑な肝を二横指触知した. 脾は触知せず, 神経学的にも異常は認めなかった。

入院時一般検查は Table 1 K示すように, 尿中ビリ ルビン陽性, RBC $494 \times 10^{4} / \mathrm{mm}^{3}, \mathrm{Ht} 34.2 \%$, Hb 11.2 $\mathrm{g} / \mathrm{d} l$ と小球性低色素性貣血を認めた。肝機能検查は, 総ビリルビン6.4mg/d $l$, GOT $1,170 \mathrm{u}$, LDH 767u, ALP 44.2u と上昇を認めたが, GPTは11u と上昇は 認めなかった。 また, CPK 10IU/L, HBD 238IU/L と ほぼ正常，心電図す異常なく心筇梗塞は否定された。 腎機能，電解質，脂質系は正常でアミノ酸分析も含め 代謝異常を示唆する所見は認めなかった，HB関連抗 
Table 1 Laboratory data on admission.

\begin{tabular}{|c|c|c|c|}
\hline \multicolumn{4}{|c|}{$\begin{array}{l}\text { urine; bil. (H) prot. (-) } \\
\text { fecal occult blood }(-)\end{array}$} \\
\hline $\mathrm{RBC}$ & $494 \times 10^{4} / \mathrm{mm}^{3}$ & CRE & $0.6 \mathrm{mg} / \mathrm{d} l$ \\
\hline $\mathrm{Ht}$ & $34.2 \%$ & $\mathrm{Na}$ & $138 \mathrm{mEq} / \mathrm{L}$ \\
\hline $\mathrm{Hb}$ & $11.2 \mathrm{~g} / \mathrm{d} l$ & $\mathrm{~K}$ & $3.8 \mathrm{mEq} / \mathrm{L}$ \\
\hline WBC & $4,100 / \mathrm{mm}^{3}$ & $\mathrm{Cl}$ & $106 \mathrm{mEq} / \mathrm{L}$ \\
\hline PLT & $24.6 \times 10^{4} / \mathrm{mm}^{9}$ & $\mathrm{Ca}$ & $9.0 \mathrm{mg} / \mathrm{d} l$ \\
\hline \multicolumn{2}{|c|}{ WBC diff.; normal } & $P$ & $4.5 \mathrm{mg} / \mathrm{d} l$ \\
\hline $\mathrm{TP}$ & $7.5 \mathrm{~g} / \mathrm{d} l$ & Т.СНO & $204 \mathrm{mg} / \mathrm{d} l$ \\
\hline T.Bil & $6.4 \mathrm{mg} / \mathrm{d} l$ & TG & $62 \mathrm{mg} / \mathrm{d} l$ \\
\hline D.Bil & $5.2 \mathrm{mg} / \mathrm{d} l$ & \multirow{2}{*}{\multicolumn{2}{|c|}{$\begin{array}{l}\text { Protogram; normal } \\
\text { CRP (-), TPHA (-) }\end{array}$}} \\
\hline GOT & $1170 \mathrm{U}$ & & \\
\hline GPT & $11 \mathrm{U}$ & HBsAg & $81.7^{*}$ \\
\hline LDH & $767 \mathrm{U}$ & $\mathrm{sAb}$ & $0.4^{*}$ \\
\hline ALP & $44.2 \mathrm{U}$ & $\mathrm{eAg}$ & $2.1^{*}$ \\
\hline LAP & $598 \mathrm{U}$ & $\mathrm{eAb}$ & $42.3^{\cdots}$ \\
\hline$\gamma$-GTP & $98^{\circ} \mathrm{IU} / \mathrm{L}$ & $\mathrm{cAb}$ & $100.0^{* *}$ \\
\hline S-AMY & $257 \mathrm{IU} / \mathrm{L}$ & \multicolumn{2}{|c|}{ Amino acid analysis: } \\
\hline U-AMY & $1688 \mathrm{IU} / \mathrm{L}$ & & normal \\
\hline $\mathrm{CPK}$ & $10 \mathrm{IU} / \mathrm{L}$ & \multicolumn{2}{|c|}{ Hb analysis; normal } \\
\hline HBD & $238 \mathrm{IU} / \mathrm{L}$ & \multicolumn{2}{|c|}{ Chromosome analysis; } \\
\hline BUN & $11 \mathrm{mg} / \mathrm{d} l$ & & normal \\
\hline
\end{tabular}

原抗体は，HBs 抗原陽性， HBs 抗体陰性， HBe 抗原 陽性, $\mathrm{HBe}$ 抗体陰性, $\mathrm{HBc}$ 抗体は高力価陽性であっ た.

入院後の経過は，Fig. 1 に示すょうに，約30病日に は, GOT 69u, ALP 15.4u, LDH 250u, 総ビリルビ ข $0.8 \mathrm{mg} / \mathrm{d} l$ と安静加療によりほぼ正常値にまで回復 した. GPT は入院時から10u 前後之ずっと正常範国で 推移し，入院第 10 病日以後は $1 \sim 2 \mathrm{u}$ と逆に低值を示す ようになった。

また，HB 関連抗原抗体系の変動をみると全経過を 通して HBs 抗原陽性, HBs 抗体陰性であり, HBc 抗 体は常に高力価陽性を持続した。一方, HBe 抗原は 3 月22日に陰性化し，逆に HBe 抗体は 5 月23日には陽 性となり seroconversionを認めている。

第 3 病日に施行した訮生検組織の H-E染色と Massonn-trichrome 染色を Fig. 2 に示す。肝小葉構 造は保たれ，門脈域の細胞浸潤や，細網線維の増生む 軽度であった。

Table 2 は，本症例の GPT に対する自己抗体ある いは,インヒビターの有無をみたものである、GPT 高 値を示す他の患者血清を, 本症例の非加熱血清, $56^{\circ} \mathrm{C}$, 30 分加熱血清抒よび生理食塩水と各々，室温で14時間

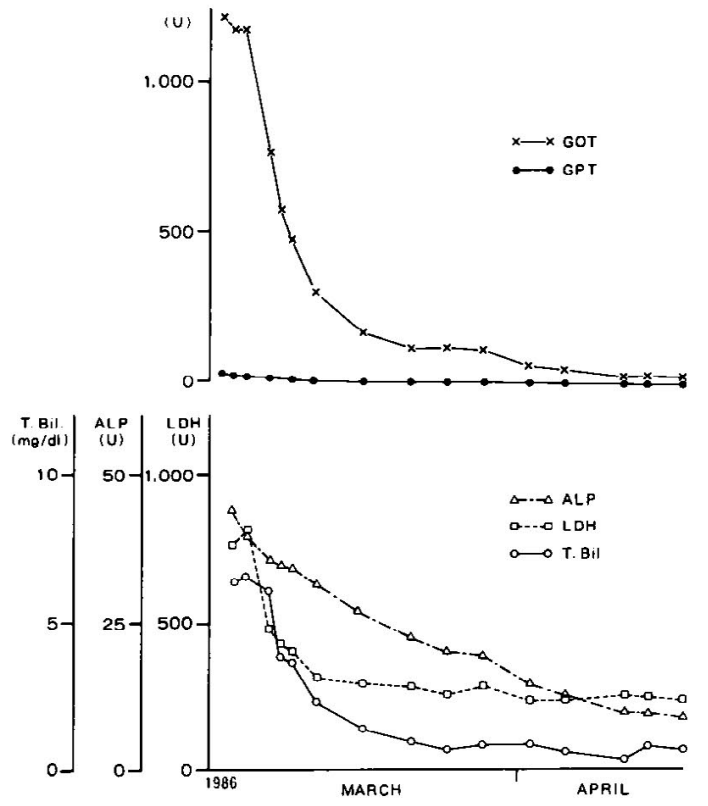

Fig. 1 Clinical course.

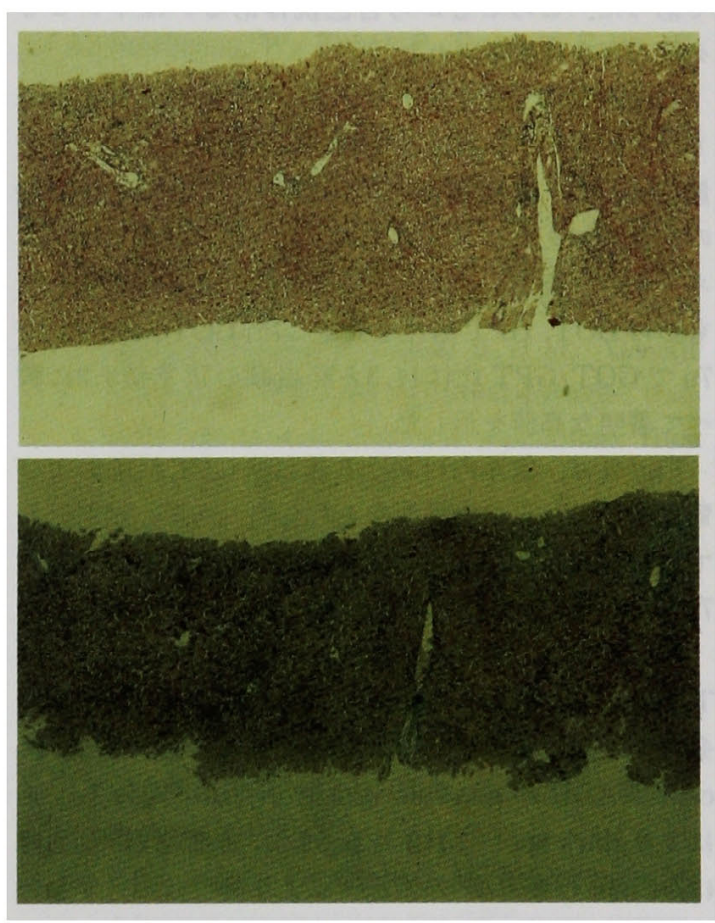

Fig. 2 Liver biopsy specimen shows slightly infiltration of inflammatory cells and reticulum fiber. A: H.E. stain $\times 40, \quad B:$ Massonn-trichrome stain $\times 40$. 
Table 2 Test for the detection of autoantibody and inhibitor.

\begin{tabular}{|c|c|c|c|c|}
\hline & & GOT & GPT & $\mathrm{LDH}$ \\
\hline $0.9 \% \mathrm{NaCl}+$ & f high GPT activity & 139 & 216 & 338 \\
\hline patient serum + & $" 1$ & 846 & 265 & 864 \\
\hline $\begin{array}{l}\text { heated patient serum }+ \\
\left(56^{\circ} \mathrm{C}, 30 \mathrm{~min}\right)\end{array}$ & " & 171 & 224 & 440 \\
\hline $0.9 \% \mathrm{NaCl}+$ & patient serum & 681 & $<3$ & 568 \\
\hline $0.9 \% \mathrm{NaCl}+$ & heated patient serum & 11 & $<3$ & 161 \\
\hline
\end{tabular}

Table 3 GPT activity of liver biopsy homogenate (Concentration of cytosol fraction is $0.1 \mathrm{~g} / \mathrm{m} l$ ).

\begin{tabular}{r|cr} 
GOT & $310 I U$ & \\
GPT & 7 IU \\
GOT/GPT & 44.3 & $\left(3.2^{*}\right)$ \\
\hline \multicolumn{2}{|c}{} \\
"normal ratio
\end{tabular}

反応させ GOT, GPT, LDH の各活性を測定した。 GPT 高値の他の患者血清に本症例の血清を加えても， 対照とした生理食塩水を加えた GPT 活性とにほとん ど差はなく，また加熱血清を加えた場合も同様の結果 であった。このことから自己抗体あるいはインヒビ ターの存在は否定された。

Table 3 は, 肝生検ホモジェネートの可溶性画分の トランスフミナーゼ活性を測定した結果である。湿重 量 $13 \mathrm{mg}$ の肝生検組織に0.25Mのショ糖液を $9 \mathrm{~m} l / \mathrm{g}$ の割合で加えホモジェナイズした。得られたホモジェ ネートの分画遠心により，可溶性画分の10倍希釈した ものの GOT, GPT 活性を測定した. GOT 310u, GPT $7 \mathrm{u}$ で GOT/GPT 比は 44.3 と肝組織の正常值 3.2 較 べて著明な高値を示した。

Fig. 3は，家系内における赤血球 GPT 活性および 電気泳動からその表現型をみたものである。試料とし て用いた赤血球は, 生理食塩水で 3 回洗浄した後, 一 $70^{\circ} \mathrm{C}$ に保存し，測定直前に溶解した。

電気泳動は, $12 \%$ starch gel を用い, $\mathrm{pH} 7.4,0.1 \mathrm{M}$ Tris-malate-EDTA buffer にて8 $\sim 9 \mathrm{~V} / \mathrm{cm}, 18$ 時間の 条件下で泳動した. GPT isoenzyme の位置は fluorescent NADH が non-fluorescent NAD に変わること により dark spot で示される。 また, 赤血球 GPT 活性

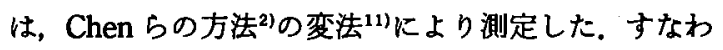
ち transaminaseによってつくられた pyruvateを2, 4-dinitrophenylhydrazine と反応させて得られた hydrazoneをアルカリで処理すると発色する。 その色 の強さが pyruvateおよびGPT 活性のレベルと比例

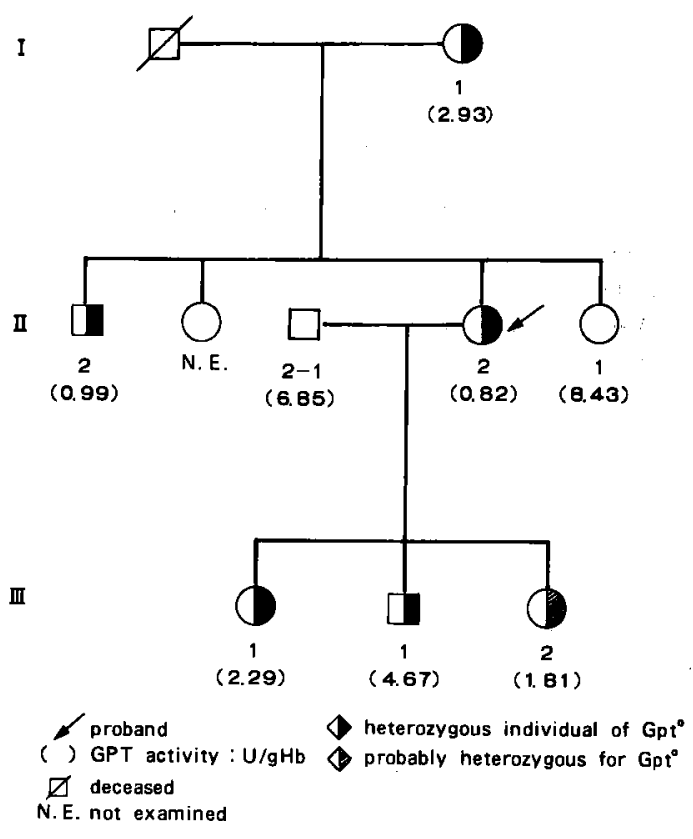

Fig. 3 Red cell GPT phenotypes and activities in the family.

することを利用した。本症例の赤血球 GPT 活性は $0.82 \mathrm{u} / \mathrm{g} \mathrm{Hb}$ で，電気泳動では GPT 2 型の泳動帯に一 致して非常に活性の弱いスポットとして描出された。 この GPT 活性は正常の GPT 2 型の平均値2.65と比 較して著明に低下した值であった。 また，本症例の家 系内の GPT 表現型と活性值は Fig. 3 のごとく，母親 GPT 1 (2.93), 兄 GPT 2 (0.99), 姝 GPT 1 (8.34), 長女 GPT 1 (2.29), 長男 GPT 1 (4.67), 次女 GPT 2 (1.81)，夫GPT 2-1 (6.85) であった．本症例の兄 については, 表現型, 活性値とも本症例に酷似してお ク，その泳動像は本症例と同様, GPT 2 型の泳動デー ンに淡いスポット状のバンドとして認められた。

他の遺伝的マーカーについては, ABO, MNs を含む 6 種の血液型, ACP, PGM-1，PGM-1サブタイプ, 
GOT, EsD, GLO, ADA, 6-PGD の酔素型, Hp, Tf, $\mathrm{CrP}, \mathrm{Gc}, \mathrm{Gc}$ サブタイプの血清型各種について調べら れたが，世代 I，II，IIIの間に表現型解離は認められ ず，遺伝的不合理は証明されなかった。

また, 本症例の Q-，G一染色法による染色体分析に も異常は認められなかった。

われわれは，以上の結果と，本症例が電気泳動上母 親の GPT 1とは遺伝的に解離を示すGPT 2であり， また赤血球 GPT 活性が 0.82 と正常の 2 分の 1 以下の 値を示したことから，同一のパターンを示す兄と同様 に $G p t^{2} G p t^{0}$ の GPT silent allele heterozygote 推 定した.

\section{考 案}

1971年にChen と Giblett がヒト赤血球中の sGPT が遣层的变異を示すことを報告1)して以来，種々の民 族で $G p t^{1}$ と $G p t^{2}$ の遺伝子頻度が明らかにされてき $た^{2,13 \sim 15)}$. その表現型は, GPT 1, GPT 2-1, GPT 2 の 3 種類からなり，常染色体遺云子座の二つの対立遺 伝子によって決定されている。 また， $G p t^{1}$ と $G p t^{2}$ の common allele $に$ 加克, GPT silent allele $\left(G p t^{0}\right)$ を 含む種々の稀な variant の報告すなされてきた。

本症例は，HB関連抗原抗体系の变動からみて

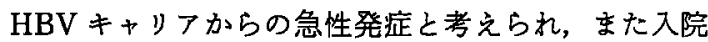
時の肝機能検查で GOT, GPT の著明な解離を示し， GPT に対する自己抗体やインヒビターの存在が否定 されたため $G p t^{0}$ の関与が示唆された症例である。

Olaisen ら ${ }^{6}$ は $G p t^{0}$ allele の頻度を4,148人のノル ウェイ人で $0.4 \%$ ，赤血球 GPT 活性はぜ口かあるい は非常に低い醇素活性を示すと報告している，本邦で

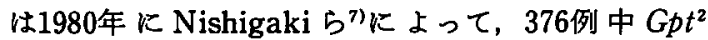
$G p t^{0}, G p t^{1} G p t^{0} \not \mathbf{3}$ 各 1 例， $0.3 \%$ とほぼ Olaisen らの 頻度と同じ報告がなされている。

三つの common phenotype の赤血球 GPT 活性に ついては, GPT 1は GPT 2に較べて 2 3 倍の値をと ク，GPT 2-1はその中間の值をとるとされている. Nishigaki らは，日本人376人について GPT 1, GPT 2-1，GPT 2, の各々の赤血球 GPT 活性の平均値を， $6.47,2.65 ， 4.52$ と報告した。

本症例は和そらく0.3〜0.4\%の頻度で存在する $G p t^{0}$ と䤃素活性の低い isoenzyme を産み出す $G p t^{2}$ の heterozygote であったために, GOT 1,170u の急性発 症の極期においても GPT は11u と非常に低值を示し たものと考えられた。
結 語

$\mathrm{HBV} キ ャ リ ア か ら の$ 急性発症を契機に見出された GPT silent allele $\left(G p t^{0}\right)$ の 1 例を経験したので若千 の文献的考察を加光て報告した。

\section{文献}

1) Chen SH, Giblett ER: Polymorphism of soluble glutamic-pyruvic transaminase: A new genetic marker in man. Science $173: 148-149$, 1971

2) Chen SH, Giblett ER, Anderson JE, et al: Genetics of glutamic-pyruvictransaminase : Its inheritance, common andrare variants, population distribution and differences in catalytic activity. Ann Hum Genet 35: 401-409, 1972

3) Olaisen B: Two rare GPT phenotypes in a Norwegian family : Evidence of seventh allele. Humangenetik 19 : 289-291, 1973a

4) Santachira Benerecetti AS, Beretta M, Pampiglione S: Red cell glutamic-pyruvic transaminase polymorphism in a sample of the Italian population: A new variant allele : $G p t^{8}$. Hum Hered $25: 276-278,1975$

5) Spielmann W, Kuhnl P, Rexrodt $C$, et al: Untersuchungen zum GPT-System unter besonderer Berucksichtigung des stummen Allels $G p t^{\circ}$. Humangenetik $18: 341-348,1973$

6) Olaisen B : Atypical segregation of erythrocyte glutamic-pyruvic transaminase in Norwegian family. Hum Hered 23 : 595-602, 1973b

7) Nishigaki I, Itoh $T$, Suzuki $H$, et al: Genetic studies of red cell glutamic-pyruvic transaminase in some Japanese populations. Hum Hered $30: 33-38,1980$

8) Mithal $Y$, Lane $A B$, Jenkins $T$ : Absence of red cell glutamic-pyruvate transaminase: Discovery of a "Silent" allele homozygote. Am J Hum Genet 32 : 42-46, 1980

9) Crist M, Heckenlively JR, Field LL, et al: Glutamate pyruvate transaminase null allele $\left(G p t^{0}\right)$ in the Navajo. Hum Hered 35: 59-61, 1985

10) Schlesinger D, Halasa J, Manczak $M$ : Atypical segregation in the GPT group system : Determination of types and activity of enzyme in families. Arc Imm Therp Exp $34: 149-155$, 1986 
11) Nishigaki I, Suzuki H, Fujiki $N$, et al : Genetic polymorphism of human red cell glutamic-pyruvic transaminase in an isolated community in western Japan. Jap J Hum Genet $23: 9-15,1978$

12) Ishimoto $G$, Kuwata $M$ : Red cell glutamicpyruvic transaminase polymorphism in Japanese population. Jap J Hum Genet $18: 373$ $-377,1974$

13) Olaisen B : Distribution of GPT types in Nor- way. Hum Hered $25: 20-29,1975$

14) Welch SG, Mills PR, Graenss RE: Phenotypic distributions of red cell glutamate-pyruvate transaminase (E.C.2.6.1.2) isoenzymes in British and New York populations. Humangenetik 27 : 59-62, 1975

15) Blake NM: Glutamic pyruvic transaminase and esterase $\mathrm{D}$ types in the Asian-Pacific area. Hum Genet $35: 91-102,1976$

\title{
A GPT silent allele found in a case with acute exacerbation of HBV carrier
}

\author{
Hiroshi Kawashima, Yoshihide Fujiyama, Akira Ando, Keiko Hodohara, \\ Shinobu NaKaJYo, Tadao BamBa, Shiro HosodA*, Takaaki OHTSUKI**, \\ Toshimasa KAJINAMI*** and Itsuro NISHIGAKI****
}

Soluble fraction of GPT (sGPT) exhibits genetic polymorphism by two autosomal codominant alleles, $G p t^{1}$ and $G p t^{2}$. The catalytic activity of the $G p t^{1}$ product is $2 \sim 3$ times higher than that of $G p t^{2}$.

The existence of a silent allele $\left(G p t^{\circ}\right)$ has also so far been predicted by several authors.

The proband, a 47-year-old female with acute exacerbation of HBV carrier, showed a remarkably low value of serum GPT activity, comparing with the elevated value of GOT, LDH, ALP at admission.

In red cell lysates the GPT activity was $0.82 \mathrm{U} / \mathrm{gHb}$ and a very weak band in its electrophoresis corresponded with the phenotype GPT2, GPT phenotype and activity of her mother were GPT1 and $2.93 \mathrm{U} / \mathrm{gHb}$, respectively.

Low value of GPT in red cell lysates and a discrepancy in phenotype between the mother and the proband could be explained by the existence of $G p t^{0}$ which does not participate in determining the phenotypes.

\footnotetext{
* Second Department of Internal Medicine, Shiga University of Medical Science (Shiga)

** Department of Central Laboratory, Shiga University of Medical Science (Shiga)

*** Department of Internal Medicine, Nishikyoto Hospital (Kyoto)

**** Department of Internal Medicine, Kohoku General Hospital (Kohoku)
} 